\title{
STRATEGI PEMASARAN SWALAYAN PAMELLA DALAM PERSPEKTIF ISLAM \\ (Studi Kasus Swalayan Pamella Yogyakarta Tahun 2010)
}

\author{
Arie Rachmat Sunjoto \\ (Dosen Ekonomi Islam ISID Gontor)
}

\begin{abstract}
This research is meant to scrutinize expansion strategy of Pamela Supermarket marketing at Yogyakarta Special Province, covering the marketing urgency for company demands and a marketing shift from conventional system to shari'ah-based one. In order to verify this work, the researcher utilizes surveys with purposive sampling method of 20 respondents who are knowledgeable and involved in expansion strategy of Pamela Supermarket marketing at Yogyakarta Special Province; and collects data through observation, questionnaires, interviews, and documentations which are analyzed by Internal-External Matrix and Analytical Hierarchy Process.

The result of research shows that alternative strategic concept used to develop marketing strategy of Pamela Supermarket at Yogyakarta Special Province based on internal and external factors which are analyzed by Internal-External Matrix are: 1) development and improvement of cooperate networking intensity; 2) improvement of product distribution capacity; 3) improvement of product availability capacity; 4) people purchasing power; and 5) development of product diversification. Besides, according to further analyzed result by Analytical Hierarchy Process, priorities of expansion strategy of Pamela Supermarket marketing at Yogyakarta Special Province are: 1) to deal with government industrial, trade and cooperative agency - to support business operations through workshops; 2) to create new concepts to attract consumers, add product variant, and promote products effectively; 3 ) to change merchandise position, add product variant, and give good service; 4) to develop product diversification, product distribution system, and work together with small and medium business in villages.

To conduct alternative strategy of marketing requires coordination with government and private sectors of economic, social and political fields though the goal of Islamic economic is to pursue shari'ah values and build a blessed business.

Keyword: Marketing Strategy, Distribution, Diversification
\end{abstract}

\section{A. Latar Belakang}

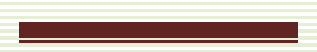

JESI

JURNAL EKONOMI SYARIAH INDONESIA
Pemasaran adalah salah satu bentuk muamalah yang dibenarkan dalam
Islam, sepanjang dalam segala proses transaksinya terpelihara dari hal-hal yang terlarang oleh ketentuan syariah. Kotler mendefinisikan pemasaran sebagai "sebuah proses sosial dan manajerial di mana individu-individu dan kelompokkelompok mendapatkan apa yang mereka butuhkan dan inginkan melalui penciptaan, penawaran, dan pertukaran produk-produk atau nilai dengan pihakpihak lainnya". Definisi ini berdasarkan konsep-konsep inti seperti kebutuhan, keinginan dan permintaan, produk-produk (barang-barang layanan, dan ide) nilai, biaya dan kepuasan, pertukaran dan transaksi, hubungan dan jaringan, pasar dan para pemasar, serta prospek.

Argumentasi di atas secara ringkas didukung oleh pendapat Kartajaya dan Sula yang menyatakan bahwa pemasaran adalah sebuah disiplin bisnis strategis 
yang mengarahkan kepada proses penciptaan, penawaran, dan perubahan nilai dari suatu inisiator kepada stakeholders-nya. Definisi formal yang dikatakan oleh asosiasi Pemasaran Amerika bahwa pemasaran adalah satu fungsi organisasi dan seperangkat proses untuk menciptakan, mengkomunikasikan, dan menyerahkan nilai kepada pelanggan serta mengelola hubungan pelanggan dengan cara yang menguntungkan organisasi dan para pemilik saham. Sedangkan konsep pemasaran menegaskan bahwa kunci untuk mencapai tujuan organisasi yang ditetapkan adalah perusahaaan tersebut harus menjadi lebih efektif dibandingkan para pesaing dalam menciptakan, menyerahkan, dan mengkomunikasikan nilai pelanggan kepada pasar sasaran yang terpilih).

Menurut Kartajaya dan Sula syariah marketing adalah sebuah disiplin bisnis strategis yang mengarahkan proses penciptaan, penawaran, dan perubahan nilai dari suatu inisiator kepada stakeholders-nya, yang dalam keseluruhan prosesnya sesuai dengan akad dan prinsip-prinsip muamalah (bisnis) dalam Islam. Ini artinya bahwa dalam syariah marketing, seluruh proses, baik proses penciptaan, proses penawaran, maupun proses perubahan nilai, tidak boleh ada hal-hal yang bertentangan dengan akad dan prinsip-prinsip muamalah yang Islami.

Maka strategi pemasaran Islam adalah puncak dari marketing itu sendiri. Spiritual marketing adalah sebagai jiwa dalam bisnis. Ia bagai pelita yang menerangi lingkungannya, memancarkan cahaya kebenaran, di tengah-tengah kegelapan. Meluruskan praktik-praktik pemasaran yang menyimpang seperti kecurangan, kebohongan, propaganda, iklan palsu, penipuan, kezaliman, dan sebagainya.

Islam telah memberikan arahan yang sangat jelas untuk melaksanakan muamalah yang baik dalam berdagang. Allah SWT telah berfirman dalam AlQuran tentang berdagang agar tidak hanya mendapat untung dan tidak merugikan satu sama lain. Allah SWT berfirman dalam surat Al-Baqarah Ayat 42 yang artinya:

"Dan janganlah kamu campur adukkan yang hak dengan yang

bathil dan janganlah kamu sembunyikan yang hak itu sedang kamu mengetahui".

Bank Indonesia menunjukkan perkembang institusi syariah dalam hal ini adalah lembaga keuangan syariah di Indonesia maka mengacu pada laporan Bank Indonesia pada bulan Desember 2009 pertumbuhan lembaga keuangan syariah di Indonesia mengalami peningkatan yang cukup signifikan. Jumlah Bank Umum Syariah pada tahun 2005 sebanyak 305 kantor, pada akhir Desember 2009 meningkat menjadi 711 kantor. Kemudian unit usaha syariah pada tahun 2005 sejumlah 154 kantor, pada akhir tahun 2009 meningkat menjadi 287 kantor. Sedangkan Bank Pembiayaan Rakyat Syariah pada tahun 2005 sebanyak 92 kantor, pada Desember 2009 meningkat menjadi 225 kantor. Sehingga total kantor untuk lembaga keuangan syariah pada tahun 2005 sebanyak 550 kantor, di bulan Desember 2009 meningkat menjadi 1223 kantor.

Contoh penerapan strategi pemasaran Islam yang muncul saat ini adalah kasus ketika orang sulit memasarkan perumahan di Bandung, misalnya, cukup dengan sekali imbauan oleh Aa Gym dalam siaran radio di pagi hari, maka perumahan yang ditawarkan habis terjual 400 unit hanya dalam waktu kurang dari satu bulan, bahkan masih terdapat 200 orang yang dalam daftar tunggu. Inilah hasil nyata dari strategi pemasaran Islam.

Kepedulian Islam terhadap masalah muamalah khususnya dalam jual-beli telah dimulai sejak permulaan Islam diturunkan. Islam telah memberikan solusi dan telah dipraktekkan sejak masa Nabi Muhammad Rasululah SAW (579) hingga saat ini. Afzalurrahman dalam bukunya berjudul Muhammad sebagai seorang

Arie

Rachmat 
pedagang menerangkan bahwa Nabi Muhammad SAW benar-benar mengikuti prinsip-prinsip perdagangan yang adil dalam transaksi-transaksinya. Selain itu ia juga selalu menasehati para sahabatnya untuk melakukan hal serupa. Ketika berkuasa dan menjadi kepala negara Madinah, ia telah mengikis habis transaksitransaksi dagang dari segala macam praktik yang mengandung unsur-unsur penipuan, riba, judi, ketidakpastian, keraguan, eksploitasi, pengambilan untung yang berlebihan dan pasar gelap. Ia juga melakukan standarisasi timbangan dan ukuran, serta melarang orang-orang tidak mempergunakan standar timbangan dan ukuran lain yang kurang dapat dijadikan pegangan. Salim menulis, Rasulullah SAW telah bersabda tentang jual-beli yang baik sebagai berikut:

"Dari Rifa'at Ibni Rofi' R.A.: bertanya kepada Rasulullah SAW: apakah profesi yang paling baik? Rasulullah menjawab: "Usaha tangan manusia sendiri dan setiap jual-beli yang diberkati".(HR. Al-Bazaar dan AL-Hakim)

Kotler menyebutkan bahwa dalam (marketing management) perencanaan strategi divisi dan perusahaan sangat penting guna menetapkan misi perusahaan, mendefinisikan bisnis, menilai peluang pertumbuhan. Hal ini bisa dapat menggunakan perencanaan strategi unit bisnis melalui misi bisnis, analisis SWOT juga digunakan sebagai alat perencanaan strategi guna analisis peluang, dan ancaman eksternal bisnis, analisis kekuatan dan kelemahan internal, perumusan sasaran, perumusan strategi, perumusan program pendukung, pelaksanaan program, dan pengumpulan umpan balik serta pelaksanaan pengendalian.

Untuk mengetahui letak kesulitan dari dalam kelemahan - kekuatan dan dari luar peluang - tantangan. Perlu dianalisa dengan teliti sehingga mejadi mozaik yang baik untuk ditiru dan diambil teladan. Maka dalam penelitian ini diambil dengan cara meneliti kedua faktor tersebut harus dipertimbangkan dalam analisis internal faktor dan eksternal faktor.

Penelitian strategi pemasaran ini adalah menganalisis letak kesulitan dari dalam kelemahan - kekuatan dan dari luar peluang - tantangan pada Swalayan Pamella. Perlu dianalisa dengan teliti sehingga mejadi mozaik yang baik untuk ditiru dan diambil teladan. Maka dalam penelitian ini diambil dengan cara meneliti kedua faktor tersebut harus dipertimbangkan dalam analisis internal faktor dan eksternal faktor (David, 2002).

\section{B. Landasan Teori}

\section{B.1. Pemasaran}

Kotler menulis pengertian pemasaran secara luas merupakan tukar menukar antara individu maupun organisasi yang melibatkan sebagian besar aspek kehidupan dalam masyarakat. Hubungan ini tidak terbatas pada aspek bisnis saja, namun dapat melibatkan aspek sosial, politik dan teknologi. Pemasaran merupakan salah satu dari kegiatan-kegiatan pokok yang dilakukan oleh para pengusaha dalam usahanya untuk mempertahankan kelangsungan hidupnya, untuk berkembang dan mendapatkan laba. Beberapa ahli telah mengemukakan definisi tentang pemasaran yang kelihatannya agak berbeda meskipun sebenarnya sama. Perbedaan ini disebabkan mereka meninjau dari segi yang berbeda. Kotler memberikan definisi pemasaran sebagai berikut:

"Prospek sosial dan manajerial dimana seseorang atau kelompok memperoleh apa yang mereka butuhkan dan inginkan melalui penciptaan dan pertukaran produk dan nilai".

Sedangkan pemasaran menurut Stanton mendefinisikan pemasaran

Strategi

Pemasaran sebagai:

"Suatu sistem keseluruhan dari kegiatan-kegiatan bisnis yang ditujukan untuk merencanakan, menentukan harga, mempromosikan, dan mendistribusikan 
barang dan jasa yang memuaskan kebutuhan baik kepada pembeli yang ada maupun pembeli potensial".

\section{B.2. Pengertian Manajemen Pemasaran}

Definisi manajemen pemasaran menurut Kotler Manajemen pemasaran adalah analisis perencanaan, penerapan, dan pengendalian terhadap program yang dirancang untuk menciptakan, membangun dan mempertahankan pertukaran dan hubungan yang menguntungkan dengan pasar sasaran dengan maksud untuk mencapai tujuan organisasi. Manajemen terjadi bila setidaknya satu pihak dalam pertukaran potensial memikirkan sasaran dan cara mendapatkan tanggapan yang dikehendaki dari pihak lain.

\section{B.3. Kepuasan Konsumen}

Menurut Tjiptono pada dasarnya tujuan dari suatu bisnis adalah untuk menciptakan para pelanggan merasa puas. Terciptanya kepuasan pelanggan dapat memberikan beberapa manfaat, diantaranya hubungan antara perusahaan dan pelanggannya menjadi harmonis, memberikan dasar yang baik bagi pembelian ulang dan terciptanya loyalitas pelanggan, membentuk suatu rekomendasi dari mulut ke mulut yang menguntungkan bagi perusahaan.

\section{B.4. Perilaku Konsumen}

Swastha menjelaskan bahwa perusahaan perlu mengetahui adanya macam faktor yang dapat memberikan alasan mengapa seseorang membeli suatu produk. Selain jenis produk, faktor demografi, dan faktor ekonomi, faktor psikologis juga dapat mempengaruhi pembelian seseorang, yang termasuk faktor psikologis ini adalah; motif, sikap, keyakinan, minat, dan kepribadian

Menurut kotler definisi perilaku konsumen adalah:

"Sebagai tindakan yang langsung terlibat dalam mendapatkan, mengkonsumsi dan menghabiskan produk dan jasa, termasuk proses keputusan yang mendahului dan menyusuli tindakan ini".

Dari definisi di atas, ada dua elemen penting dari arti perilaku konsumen yaitu proses pengambilan keputusan dan kegiatan fisik, yang semua ini melibatkan individu dalam menilai, mendapatkan, dan mempergunakan barangbarang dan jasa-jasa ekonomis. Dalam mempelajari perilaku konsumen di mulai dengan meneliti siapa-siapa saja yang disebut dengan konsumen.

\section{B.5. Model Perilaku Konsumen}

Perilaku konsumen harus merupakan sesuatu yang komplek, karena banyak variabel yang mempengaruhi. Variabel-variabel itu cenderung saling berinteraksi. Baik itu dari proses pengambilan keputusan untuk membeli sampai akan memakai suatu produk atau jasa. Jadi pemahaman perilaku konsumen ini meliputi juga pertanyaan siapa pembeli itu, bagaimana mereka membeli, dimana mereka membeli, dan mengapa mereka membeli.

Model perilaku konsumen yang lebih terperinci seperti terlihat pada gambar 2.1.

Gambar 2.1

Model Perilaku Konsumen

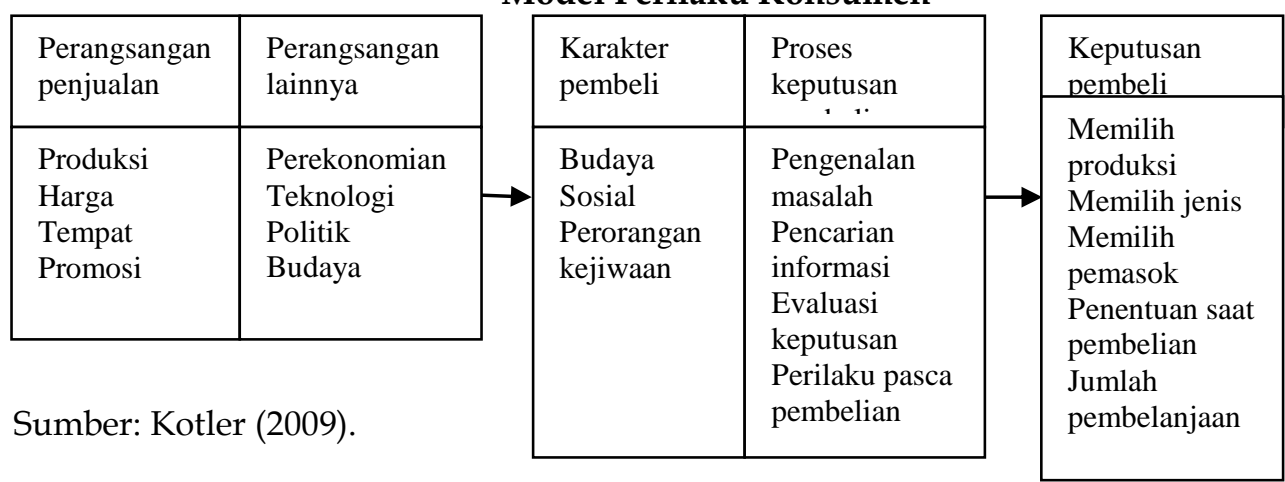

Arie

Rachmat 


\section{B.6. Teori Perilaku Konsumen}

Swastha Konsumen membeli barang dan jasa adalah untuk memuaskan berbagai keinginan dan kebutuhan. Barang dan jasa itu sendiri tidaklah sepenting kebutuhan dan keinginan manusia yang dipenuhinya. Jadi yang dibeli konsumen bukanlah barangnya sendiri akan tetapi kegunaan yang dapat diberikan barang tersebut. Dengan kata lain kemampuan barang tersebut untuk memenuhi kebutuhan dan keinginannya. Seseorang yang akan membeli suatu barang pasti ada motivasi tertentu. Adapun motif-motif yang menjadi pendorong suatu pembelian adalah; motif biologis, sosiologis, ekonomis dan agama.

Untuk mengetahui dan memahami proses motivasi yang mendasar dan mengarahkan perilaku konsumen dalam melakukan pembelian, perlu dipelajari beberapa teori perilaku konsumen sendiri, yaitu:

1. Teori Ekonomi Mikro.

2. Teori Psikologi.

3. Teori Sosiologi.

4. Teori Anthropologi.

\section{B.7. Proses Pengambilan Keputusan}

Pengambilan keputusan konsumen terhadap pembelian suatu produk merupakan suatu proses yang terdiri dari beberapa tahap, mulai dari tahap pengenalan masalah (kebutuhan dan keinginan) pencarian informasi, penilaian/seleksi alternatif, keputusan pembelian sampai tahap evaluasi pembelian dilakukan. Adapun tahap-tahap tersebut adalah dapat dilihat pada gambar berikut:

\section{Gambar 2.2}

\section{Proses Pengambilan Keputusan}

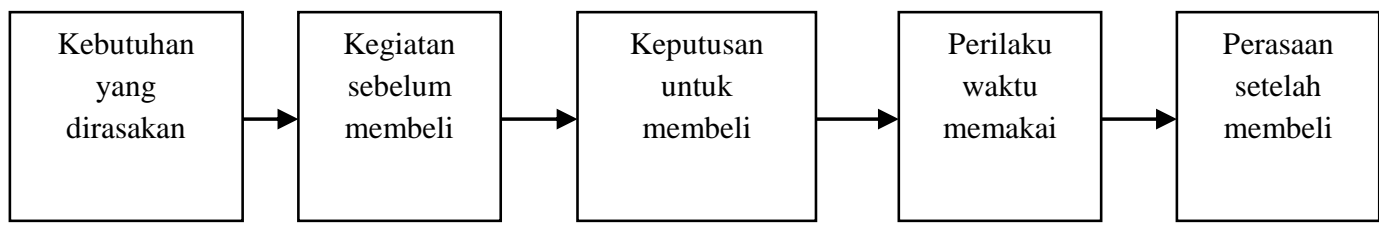

Sumber: Kotler (2007).

\section{B.8. Pengertian Bauran Pemasaran (Marketing Mix)}

Bauran pemasaran merupakan satu konsep kunci dalam teori pemasaran modern. Menurut Kotler definisi bauran pemasaran adalah seperangkat alat pemasaran yang digunakan perusahaan untuk mencapai tujuan pemasarannya dalam pasar sasaran.

Jagpal menulis tentang bauran pemasaran dengan pengembangan menggunakan modal dalam menetapkan harga sebagai rangka penilaian CAPM (Capital Asset Pricing Model). Tujuan dari tulisan ini adalah menganalisis model bauran pemasaran dengan contoh umum mentaksir harga dan iklan. Bagaimana cara menentukan bauran pemasaran. Dengan apa dimodifikasi bila konsidi pasar berubah dengan mencatat CAPM sebagai maksimalisasi nilai harga iklan dan kewiraniagaan.

Terdapat beberapa alat bauran pemasaran, Mc Charthy mempopulerkan empat variabel utama yang dikenal dengan empat P (4P) yaitu: Product, Price, Promotion dan Place.

Berikut di bawah ini akan diuraikan mengenai masing-masing elemen dari bauran pemasaran:

1. Produk (Product)

Produk merupakan elemen yang sangat penting dalam bauran pemasaran

\section{Strategi}

Pemasaran karena produk merupakan sesuatu yang ditawarkan kepada konsumen untuk dikonsumsi untuk memenuhi kebutuhan dan keinginan konsumen. Secara 
konseptual produk adalah pemahaman subyektif dari produsen atas sesuatu yang bisa ditawarkan sebagai usaha untuk mencapai tujuan organisasi melalui pemenuhan kebutuhan dan keinginan konsumen, sesuai dengan kompetensi dan kapasitas organisasi serta daya beli pasar. Konsep produk total meliputi barang kemasan, merek, label, pelayanan dan jaminan.

Selain berdasarkan daya tahannya, produk umum juga diklasifikasikan berdasarkan siapa konsumennya dan untuk apa produk tersebut dikonsumsi. Berdasarkan kriteria ini, produk dapat dibedakan menjadi barang konsumen (consumer's goods) dan barang idustri (industrial's goods).

2. Harga (Price)

Penentuan harga adalah penting bagi perusahaan. Harga merupakan satu faktor yang akan mempengaruhi permintaan, posisi persaingan dan pangsa pasar dari suatu produk. Agar dapat sukses dalam memasarkan suatu barang atau jasa, maka setiap perusahaan harus menetapkan harganya secara tepat. Harga merupakan satu-satunya unsur dalam bauran pemasaran yang memberikan pemasukan atau pendapatan bagi perusahaan, sedangkan ketiga unsur lainnya menyebabkan timbulnya biaya.

3. Promosi (Promotion)

Dalam memasarkan produknya, perusahaan harus secara aktif mengkomunikasikan kepada konsumen tentang perusahaan maupun produk yang dijualnya. Hal ini dilaksanakan agar konsumen mengetahui dan mendapatkan informasi tentang produk yang dijual oleh perusahaan. Untuk tujuan ini perusahaan dapat melakukan kegiatan promosi. Promosi merupakan salah satu faktor penentu keberhasilan suatu program pemasaran. Tujuan utama dari promosi adalah menginformasikan, mempengaruhi dan membujuk serta mengingatkan target market tentang perusahaan dan bauran pemasarannya. Sedangkan kegiatan promosi yang biasa dilakukan oleh perusahaan:

a. Iklan (advertising).

b. Promosi penjualan (sales promotion).

c. Publisitas (publicity).

d. Penjualan pribadi (personal selling).

4. Distribusi (Distribution)

Setelah perusahaan memproduksi barang, menetapkan harga jual dan mengkomunikasikan barang kepada konsumen, maka usaha yang terakhir adalah menyalurkan barang tersebut agar sampai di pasar sehingga dapat dibeli dan dinikmati konsumen dengan menyalurkan jumlah tingkatan perantara yang berbeda. Berdasarkan jumlahnya, saluran distribusi dapat dibedakan menjadi empat tingkat.

Gambar 2.4

\section{Saluran Distribusi Barang Konsumsi}

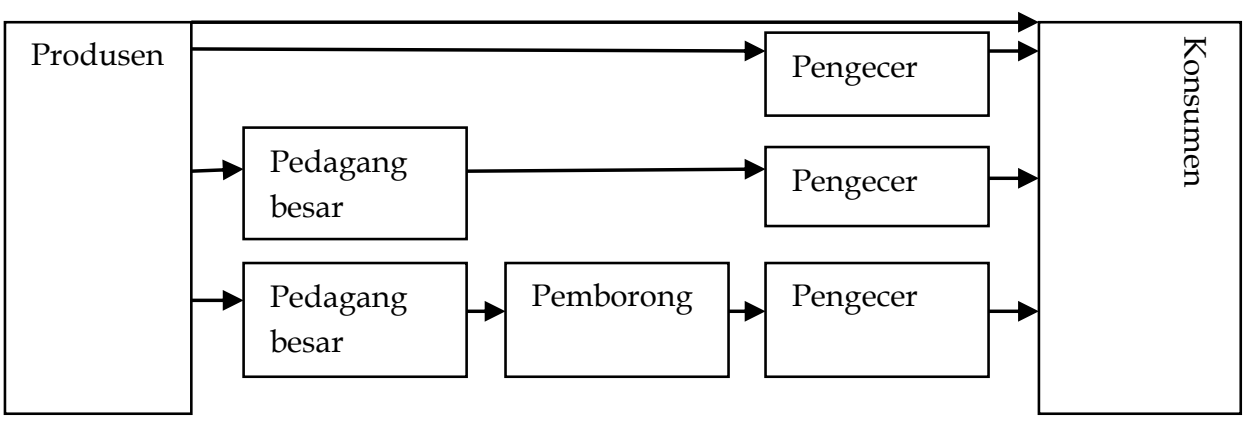

Sumber: Kotler (1997). 


\section{B.9. Manajemen Strategis}

Purwanto memaparkan manajemen strategis merupakan alat untuk mencapai tujuan pemasaran. Untuk itu menajemen strategis memegang peranan penting dalam penentuan perencanaan dan tindakan yang harus diambil. Porter selanjutnya mengambil tindakan dinamis untuk memberi respon terhadap kekuatan internal dan eksternal. Menjelang akhir abad ke-20 berubah menjadi pemahaman keinginan konsumen.

Quin secara khusus melihat strategis dari termin dan gambaran dunia militer yang mempunyai dimensi atau kriteria strategi yang sukses. Strategi merupakan seni menggunakan pertempuran untuk memenangkan suatu perang. Penggunaan strategi dalam manajemen sebuah organisasi dapat diartikan sebagai kiat, cara dan taktik utama yang dirancang secara sistematik dalam melaksanakan fungsi-fungsi manajemen, yang terarah pada tujuan strategis nasional.

Wheelen dan Hunger mengemukakan bahwa manajemen strategis merupakan seni dan ilmu untuk memformulasikan, mengimplementasikan dan mengevaluasi keputusan-keputusan lintas fungsional yang memungkinkan suatu organisasi mencapai sasarannya. Proses manajemen strategis meliputi tiga tahapan yaitu formulasi strategi, implementasi strategi dan evaluasi strategi. Manajemen strategi juga diartikan sebagai serangkaian keputusan dan tindakan manajerial yang menentukan keragaan perusahaan dalam jangka panjang. Hal ini meliputi environmental scanning baik eksternal maupun internal, formulasi strategi (Perencanaan strategis atau perencanaan jangka panjang) strategi implementasi, evaluasi dan kontrol secara sistematis.

\section{B.10. Perumusan Strategi}

Perumusan strategis adalah proses manajerial untuk menyusun dan menangani kesesuaian strategis antara tujuan dan kemampuan organisasi dengan kesempatan yang berubah-ubah. Sasaran perencanaan strategis adalah membantu organisasi memilih dan mengelola organisasi agar tetap sehat dalam kondisi apapun. Teknik perumusan strategi menurut dapat dipadukan menjadi kerangka kerja pembuatan keputusan. Tahap analisis dalam proses penyusunan strategis tersebut meliputi:

a. Tahap pengumpulan data, pada tahap ini bukan hanya sekedar mengumpulkan data, tetapi juga merupakan suatu kegiatan pengklasifikasian dan pra analisis. Pada tahap ini data dibedakan menjadi data eksternal, yaitu data yang diperoleh dari lingkungan di luar lingkup penelitian, dan data internal, yaitu data yang diperoleh dari dalam lingkup penelitian.

b. Tahap analisis, adalah tahap pemanfaatan semua informasi yang diperoleh dari pengumpulan data dengan model-model kuantitatif perumusan strategi.

c. Tahap pengambilan keputusan, dilakukan oleh pengambil keputusan dengan mendasarkan pada analisis data yang telah diperoleh secara komprehensif.

Matriks Evaluasi faktor eksternal dan internal digunakan untuk mengetahui kelemahan dan kekuatan serta mengkaji peluang dan hambatan yang dihadapi dalam melaksanakan suatu misi, baik yang bersumber pada faktor di dalam maupun diluar organisasi non profit. Matrik internal - eksternal mengumpulkan dan mengevaluasi kekuatan dan kelemahan di dalam organisasi secara fungsional untuk mengetahui posisi organisasi dalam menetapkan alternatif strategi.

\footnotetext{
Strategi

Pemasaran
} 


\section{B.11.Dasar-dasar Pemasaran Syariah}

\section{B. 11.a. Dari Era Rasional ke Emosional Spiritual}

Kartajaya dan Sula menyatakan bahwa di level intelektual "Rasional" pemasar menyikapi pemasaran secara fungsional teknikal dengan menggunakan sejumlah alat pemasaran seperti; segmentasi, targeting, positioning, marketingmix,dan branding. Kemudian di level emosional kemampuan pemasar dalam memahami emosi perasaan pelanggan sangat penting. Di sini pelanggan dilihat sebagai manusia seutuhnya, lengkap dengan emosi dan perasaannya. Jika di level intelektual otak kiri si pemasar paling berperan, di level intelektual otak kananlah yang lebih dominan. Jika di level intelektual pemasaran layaknya sebuah "robot", di level emosional pemasaran menjadi seperti "manusia" yang berperasaan dan empatik.

Seorang Muslim yang baik dalam transaksi muamalahnya, pemasaran baik sebagai pemimpin perusahaan, pemilik, pemasar, pesaing, maupun sebagai pelanggan hendaklah prinsip-prinsip keadilan, kejujuran, transparansi, etika, dan moralitas menjadi nafas dalam setiap bentuk transaksi bisnisnya. Sebagaimana firman Allah SWT dalam Al-Quran Surat An-Nahl Ayat 90 sebagai berikut:

"Sesungguhnya Allah menyuruh (kamu) berlaku adil dan berbuat

kebajikan, memberi kepada kaum kerabat, dan Allah melarang dari

perbuatan keji, kemungkaran dan permusuhan. Dia memberi pengajaran kepadamu agar kamu dapat mengambil pelajaran".

\section{B.11.b. Pemasaran Spiritual Sebagai Jiwa Bisnis}

Pemasaran spiritual bertujuan untuk mencapai sebuah solusi yang adil dan transparan bagi semua pihak yang terlibat. Di dalamnya tertanam nilai-nilai moral dan kejujuran. Tidak ada pihak yang terlihat di dalamnya merasa dirugikan. Tidak ada pula pihak yang berburuk sangka. Spritual marketing sangat syarat dengan nilai-nilai syariah dan dalam implementasinya selalu dijiwai oleh nilainilai kebenaran yang terpancar dari Al-Quran dan Sunnah Nabi. Ghani menyatakan akuntabilitas dan responsibilitas diterjemahkan sebagai pertanggung jawaban di hari akhir (yaumul hisah) kelak, yang merupakan pengadilan abadi terhadap sepak-terjang manusia termasuk para pelaku bisnis baik yang tersurat dan tersirat. Allah SWT berfirman dalam Surat Al-Qiyamah Ayat 36:

"Apakah manusia mengira, bahwa ia akan dibiarkan begitu saja (tanpa pertanggung jawaban)".

\section{B.11.c. Karakteristik Pemasaran Syariah}

Afzalurrahman menyatakan Nabi Muhammad SAW melarang beberapa jenis perdagangan, baik karena hakekat perdagangan itu memang dilarang maupun karena adanya unsur-unsur yang diharamkan di dalamnya. Memperjual belikan benda-benda yang dilarang dalam Al-Quran adalah haram. Al-Quran melarang mengkonsumsi daging babi, darah, bangkai, dan alkohol, sebagai mana firman-Nya:

"Sesungguhnya Allah hanya mengharamkan bagimu bangkai, darah, daging babi, dan binatang yang (ketika disembelih) disebut (nama) selain Allah. Tetapi barangsiapa dalam keadaan terpaksa (memakannya) sedang dia tidak menginginkannya dan tidak (pula) melampaui batas, maka tidak ada dosa baginya. Sesungguhnya Allah maha pengampun lagi maha penyayang".

Kartajaya dan Sula menyatakan bahwa ada empat karakteristik pemasaran syariah yang dapat menjadi panduan bagi para pemasar sebagai berikut:

1. Teistis (Rabbaniyah) yaitu bersifat ketuhanan ini adalah hukum yang paling adil, paling sempurna, paling selaras dengan segala bentuk kebaikan, paling dapat mencegah segala bentuk kerusakan, paling

Arie Rachmat 
mampu mewujudkan kebenaran, memusnakan kebatilan, dan menyebarluaskan kemaslahatan.

2. Etis (Akhlaqiyah) yaitu sangat mengedepankan masalah akhlak moral dan etika dalam seluruh aspek kegiatan.

3. Realistis (Al-Waqi'iyyah) yaitu pemasaran syariah bukanlah konsep yang ekslusif, fanatis, anti-modernitas, dan kaku. Akan tetapi merupakan konsep pemasaran yang fleksibel, sebagaimana keluasan dan keluwesan Syariah Islamiyah yang melandasinya.

4. Humanistis (Insaniyah) yaitu bersifat humanistis universal artinya syariah diciptakan untuk manusia agar derajatnya terangkat, sifat kemanusiaannya terjaga dan terpelihara, serta sifat-sifat kehewanannya dapat terkekang dengan panduan Syariah. Ini akan menjadikan manusia yang terkontrol, dan seimbang (tawazun) bukan manusia yang serakah, menghalalkan segala cara untuk mencari keuntungan yang sebesar-besarnya.

B.11.d. Prinsip-prinsip Pemasar Syariah

Kartajaya dan Sula menyebutkan di dalam menjalankan fungsi-fungsi pemasaran ada sembilan etika (akhlak) pemasar yaitu:

1. Memiliki Kepribadian Spiritual ( Takwa).

2. Berperilaku Baik dan Simpatik (Shidiq).

3. Berlaku Adil dalam Bisnis (Al-Adl).

4. Bersikap Melayani dan Rendah Hati (Khidmah).

5. Menepati Janji dan tidak Curang.

6. Jujur dan Terpercaya (Al-Amanah).

7. Tidak Suka Berburuk Sangka (Su'uzh-zhann).

8. Tidak Suka Menjelek-jelekkan (Ghibah).

9. Tidak Melakukan Sogok (Riswah).

B.11.e. Nilai Bisnis dan Manajemen Muhammad SAW

Berikut adalah tabel nilai bisnis dan manajemen.

Tabel 2.1

Nilai Bisnis dan Manajemen Muhammad SAW

\begin{tabular}{|c|c|c|}
\hline $\begin{array}{l}\text { No. Nilai } \\
\text { Kerasulan }\end{array}$ & Nilai dasar & $\begin{array}{c}\text { Nilai Bisnis dan } \\
\text { Manajemen }\end{array}$ \\
\hline 1. Shiddiq & Berintregitas & $\begin{array}{l}\text { Jujur } \\
\text { Tahan Uji } \\
\text { Ikhlas } \\
\text { Terjamin } \\
\text { Keseimbangan Emosional }\end{array}$ \\
\hline 2. Amanah & Terpercaya & $\begin{array}{l}\text { Kepercayaan } \\
\text { Bertanggung Jawab } \\
\text { Transparan } \\
\text { Tepat Waktu } \\
\text { Tanggung Jawab }\end{array}$ \\
\hline 3. Fathonah & Berpengetahuan luas & $\begin{array}{l}\text { Manajemen Bervisi } \\
\text { Manajer dan Pemimpin Cerdas } \\
\text { Sadar Produk dan Jasa } \\
\text { Belajar Berkelanjutan }\end{array}$ \\
\hline
\end{tabular}

\section{Strategi}

Pemasaran 


\begin{tabular}{|c|c|c|}
\hline $\begin{array}{l}\text { No. Nilai } \\
\text { Kerasulan }\end{array}$ & Nilai dasar & $\begin{array}{c}\text { Nilai Bisnis dan } \\
\text { Manajemen }\end{array}$ \\
\hline 4. Tabligh & Komunikatif & $\begin{array}{l}\text { Supel } \\
\text { Penjual Cerdas } \\
\text { Deskripsi Tugas atau Pekerjaan } \\
\text { Delegasi Wewenang } \\
\text { Kerja Tim } \\
\text { Cepat Tanggap } \\
\text { Koordinasi } \\
\text { Kendali dan Supervisi }\end{array}$ \\
\hline
\end{tabular}

\section{B.12. Strategi Pemasaran Syariah}

\section{B.12.a. Melihat Pasar Bersifat Universal (Segmentation)}

Segmentasi adalah seni mengidentifikasikan serta memanfaatkan peluangpeluang yang muncul di pasar. Pada saat yang sama ia adalah ilmu untuk melihat pasar berdasarkan variabel-variabel yang berkembang di tengah masyarakat dengan tanpa melihat suku, agama, dan budaya. Sebagai contoh, banyak sekali sekarang nasabah-nasabah lembaga keuangan syariah yang justru berasal dari kalangan non-Muslim. Jadi segmentasi bersifat komprehensif juga universal. Dengan maksud komprehensif adalah syariah Islam merangkum seluruh aspek kehidupan, baik ritual (ibadah) maupun sosial (muamalah). Keuniversalan ini jelas terutama pada bidang sosial yang tidak membeda-bedakan antara kalangan Muslim dan non-Muslim (Antonio, 2004).

\section{B.12.a. Pelayanan Hatinurani Target Konsumen (Targeting)}

Targeting adalah strategi mengalokasikan sumber daya perusahaan secara efektif, karena sumber daya yang dimiliki terbatas. Dengan menentukan target yang akan dibidik, usaha akan lebih terarah. Afzalurrahman (2000) menyatakan bahwa Nabi Muhammad SAW sangat sopan dan baik hati dalam melakukan transaksi perdagangan. Selain itu, ia juga selalu menasehati para sahabatnya untuk bersikap yang sama kapan saja dan dengan siapa saja mereka melakukan transaksi.

\section{B.12.b. Membangun Sistem Kepercayaan (Positioning)}

Kartajaya dan Sula (2006) menyatakan bahwa positioning adalah strategi untuk merebut posisi di benak konsumen, sehingga strategi ini menyangkut bagaimana membangun kepercayaan, keyakinan, dan kompetensi bagi pelanggan. Hal ini adalah aktivitas mendesain citra dari apa yang ditawarkan perusahaan sehingga mempunyai arti dan memposisikan diri di benak konsumen. Jadi, positioning adalah suatu pernyataan mengenai identitas perusahaan tertanam di benak konsumen yang mempunyai kesesuaian dengan kompetensi yang dimiliki perusahaan untuk mendapatkan kepercayaan, kredebilitas, dan pengakuan dari konsumen. Dan untuk perusahaan berbasis syariah, membangun kepercayaan berarti menunjukkan komitmen bahwa perusahaan syariah itu menawarkan sesuatu yang lebih jika dibandingkan dengan perusahaan non-syariah.

\section{B.12.c. Merancang Perbedaan yang Bermakna dalam Tawaran Perusahaan (Diferentiation)}

Diferensiasi adalah inti dari taktik pemasaran. Diferensiasi didefinisikan sebagai tindakan merancang seperangkat perbedaan yang bermakna dalam tawaran perusahaan. Diferensiasi ini berupa isi pada nilai yang ditawarkan kepada pelanggan. Bagaimana cara menawarkan yang berbentuk dalam prinsip-prinsip syariah, dan yang tak kalah penting yaitu infrastruktur yang merujuk pada teknologi, sumber daya manusia, serta fasilitas yang digunakan untuk menciptakan diferensiasi (Kartajaya dan Sula, 2006).

Arie

Rachmat 


\section{B.12.d. Kejujuran dengan 4 P (Marketing Mix)}

Marketing-mix yang dimaksud adalah bagaimana mengintegrasikan tawaran dari perusahaan dengan akses yang tersedia. Pengintegrasian ini menjadi kunci sukses usaha pemasaran dari perusahaan. $4 \mathrm{P}$ sebagai marketing-mix, yang elemennya adalah produk dan harga adalah komponen dari tawaran, tempat dan promosi adalah komponen dari akses. Komponen tawaran, produk dan harga haruslah didasari dengan nilai kejujuran dan keadilan, sesuai dengan prinsip syariah. Kualitas produk yang ditawarkan harus sesuai dengan yang ditawarkan. Sedangkan dalam harga perusahaan harus mengutamakan keadilan. Komponen akses, tempat dan promosi harus menggambarkan secara riil apa yang ditawarkan dari produk atau servis-servis perusahaan tersebut. Sehingga pada intinya, dalam menentukan marketing-mix, proses integrasi terhadap tawaran dan akses, harus didasari oleh prisip-prinsip keadilan dan kejujuran (Kartajaya dan Sula, 2000).

\section{B.12.e. Penjualan dengan Harga Kerabat (Selling)}

Menjual di sini bukanlah berarti aktivitas menjual produk kepada konsumen saja. Penjualan dalam arti sederhana adalah penyerahan suatu barang atau jasa dari penjual ke pembeli dengan harga yang disepakati atas dasar sukarela. Dalam melakukan penjualan, perusahaan tidak hanya menyampaikan fitur-fitur dari produk dan jasa yang ditawarkan saja, melainkan juga dengan keuntungan dan bahkan solusi dari produk atau jasa tersebut.

Dalam hal ini tidak boleh misalnya, menawarkan produk dengan harga yang rendah untuk memikat konsumen, tetapi kualitasnya diturunkan secara diam-diam. Konsumen mungkin akan tertarik pada awalnya. Namun, begitu mengetahui telah dikelabui, mereka pasti akan pergi meninggalkan perusahaan yang curang itu. Perusahaan atau penjual harus menganggap konsumen sebagai teman dengan sikap tolong-menolong dan kejujuran sebagai landasan utamanya. Dengan menjalin persaudaraan dengan konsumen, hubungan jankga panjang akan tercipta secara harmonis. Sehingga, pada akhirnya konsumen akan menjadi pendukung dan pembela dikala produk atau perusahaan mengalami masalah kritis (Kartajaya dan Sula, 2006).

\section{B.12.f. Nama Baik Identitas (Brand)}

Dalam pemasaran Syariah, brand adalah nama baik yang menjadi identitas seseorang atau perusahaan. Merek adalah suatu identitas terhadap produk atau jasa perusahaan. Merek mencerminkan nilai yang diberikan kepada konsumen. Disini brand yang memiliki karakter sesuai dengan syariah dan nilai spiritual, seperti brand tidak mengandung unsur riba, judi, penipuan, tidak mengandung unsur kezaliman, dan tidak membahayakan pihak sendiri dan oran lain (Kartajaya dan Sula, 2006).

Antonio (2007) menyatakan jujur adalah penyelamatan bagi guru di dunia dan di akhirat. Jika berbohong pengaruhnya sampai kepada masyarakat dan tidak terbatas pada orang yang melakukan. Allah SWT telah berfirman dalam Surat AlBayyinah Ayat 5 sebagai berikut:

"Padahal mereka tidak disuruh kecuali supaya menyembah Allah dengan memurnikan ketaatan kepada-Nya dalam menjalankan agama yang lurus, dan supaya mereka mendirikan shalat dan menunaikan zakat, dan yang demikian itulah agama yang lurus".

\section{B.12.g. Servis untuk Kepuasan Pelanggan (Service)}

Perusahaan yang berbasis syariah marketing harus memperhatikan servis yang ditawarkan untuk menjaga kepuasan pelanggan. Dalam melakukan pelayanan yang baik, biasanya digambarkan seseorang melalui sikap, pembicaraan, dan bahkan dari bahasa tubuh yang bersifat simpatik, lembut, Strategi sopan, hormat, dan penuh kasih sayang. Servis yang dimaksudkan di sini bukan Pemasaran lagi pelayanan purnajual, prajual, ataupun selama penjualan semata. Namun, bagaimana servis yang ditawarkan perusahaan dapat membantu dan 
mentransformasi kehidupan semua stakeholder perusahaan (Kartajaya dan Sula, 2006).

B.12.h. Pencerminan Proses Tingkat Kualitas, Harga dan Pengiriman (Process)

Prinsip terakhir dalam syariah marketing adalah proses. Proses mencerminkan tingakat quality, cost, dan delivery yang sering disingkat sebagai QCD. Kualitas suatu produk ataupun servis tercermin dari proses yang baik, dari proses produksi sampai pengiriman kepada konsumen secara tepat waktu dan dengan biaya yang efektif dan efisien. Proses pengiriman cukup penting karena merupakan kontak poin yang memungkinkan konsumen langsung bisa merasakan kepuasan atau tidak terhadap pelayanan perusahaan. Proses pengiriman yang tepat akan membawa nilai lebih bagi konsumen. Selain itu, proses pengiriman ini juga mempunyai makna bahwa nilai yang ditawarkan dalam sebuah produk atau servis harus sesuai dengan yang disampaikan. Disinilah kejujuran dan tanggung jawab dari perusahaan harus disampaikan sehingga dapat memberikan nilai lebih kepada konsumen (Kartajaya dan Sula, 2006).

\section{Metode Penelitian}

Metode yang digunakan dalam penelitian ini adalah metode campuran (triangulation) yaitu perpaduan antara metode kualitatif dan kuantitatif. Metode kualitatif digunakan untuk menganalisa strategi pemasaran swalayan pamella di DIY. Metode kuantitatif digunakan untuk menganalisa perubahan dan rasio analisis SWOT dengan objek Inter-Eksternal Faktor. Setelah itu dilanjutkan dengan Analisis Pemilihan Strategi dengan Analitical Hierarchy Process (AHP)

Data dikategorikan berdasarkan metode yang digunakan dalam penelitian ini. Dalam metode kualitatif lebih banyak digunakan data-data yang bersifat kualitatif baik data primer maupun data sekunder. Data-data dalam metode kualitatif dikumpulkan dengan cara observasi, wawancara dan dokumenter. Adapun metode kuantitatif digunakan data-data kuantitaitif atau hitungan yang mayoritas adalah hasil pengolahan data primer yang dikumpulkan dengan cara penyebaran angket dan wawancara dengan responden.

Teknik analisis data yang dilakukan adalah dengan deskriptif kualitatif dan kuantitatif dengan pengolahan dan analisis data.Perumusan strategi dilakukan melalui tiga tahap yaitu, tahap pertama adalah tahap masukan (input stage) dengan menggunakan matrik evaluasi faktor internal (EFI) dan evaluasi faktor eksternal (EFE). Tahap kedua yaitu tahap pemaduan (matching stage) dengan menggunakan matrik internal - eksternal. Tahap ketiga adalah tahap pemilihan alternatif strategis prioritas dengan menggunakan Analitical Hierarchy Process (AHP).

Adapun teknik pengambilan sampel adalah Purposive Sampling. Purposive Sampling adalah teknik penentuan sampel dengan pertimbangan tertentu Sugiyono. Misalnya akan melakukan penelitian tentang pengembangan strategi pemasaran, maka sampel sumber datanya adalah orang yang ahli dalam pemasaran. Jumlah sampel yang diambil sebanyak 20 orang yaitu pihak-pihak yang berpengaruh dalam pengembangan strategi pemasaran pada Swalayan Pamella di DIY.

\section{Hasil dan Pembahasan}

\section{D.1. Faktor Ekonomi}

Faktor ekonomi yang berpengaruh terhadap perekonomian di DIY adalah seperti diuraikan di bawah ini:

\section{Laju Inflasi}

Pergerakan inflasi perlu diperhatikan karena inflasi mempengaruhi kenaikan harga-harga secara umum, termasuk bahan makanan. Laju pertumbuhan ekonomi merupakan salah satu indikator perekonomian yang sering dikaitkan dengan kinerja/kemajuan pembangunan di suatu wilayah/negara. Laju pertumbuhan ekonomi dihitung berdasarkan perubahan PDRB atas dasar harga

Arie

Rachmat 
konstan tahun yang bersangkutan terhadap tahun sebelumnya. Selama lima tahun terakhir kinerja perekonomian Provinsi DIY secara umum menunjukkan perkembangan yang semakin baik/positif. Hal ini dapat dilihat dari laju pertumbuhan ekonomi selama periode 2005- 2009 yang selalu meningkat, walaupun pada periode 2005-2006 agak sedikit melambat. Pada tahun 2007 laju pertumbuhan ekonomi Provinsi DIY tercatat 3,3 persen dan meningkat menjadi 4,5 persen pada tahun 2009. Sedangkan pertumbuhan ekonomi tahun 2010 diprediksi akan membaik atau sebesar 5,3 persen dibandingkan tahun 2009 ini yang diperkirakan hanya mencapi 4,5 persen (BPS, 2009).

\section{Nilai Tukar Rupiah}

Pengaruh ketidak stabilan nilai tukar juga telah memperburuk kinerja stabilisasi harga konsumsi terhadap bahan makanan pokok maupun non pokok dalam negeri. Merosotnya nilai rupiah berpengaruh pada meningkatnya harga barang dalam negeri dan harga barang meningkat dari waktu ke waktu. Ketidak stabilan harga dalam negeri lebih dominan dipengaruhi oleh ketidakstabilan nilai tukar rupiah terhadap dolar Amerika.

\section{Survei Indeks Keyakinan Konsumen Bank Indonesia Yogyakarta 2009}

Hasil survey konsumen pada triwulan III-2009 terus menunjukkan adanya peningkatan level optimisme konsumen, yang tercermin pada indeks keyakinan konsumen (IKK) sebesr 100,15 yang meningkat tipis sebesar 0,04 poin dibandingkan triwulan sebelumnya (IKK 100,11). Faktor yang menyebabkan peningkatkan level IKK adalah kenaikan pada kedua komponen penyusun IKK, yakni indeks kondisi ekonomi (IKE) dan indeks ekspektasi konsumen(IEK) masing-masing meningkat sebesar 100,02 dan 0,01 poin menjadi 100,29.

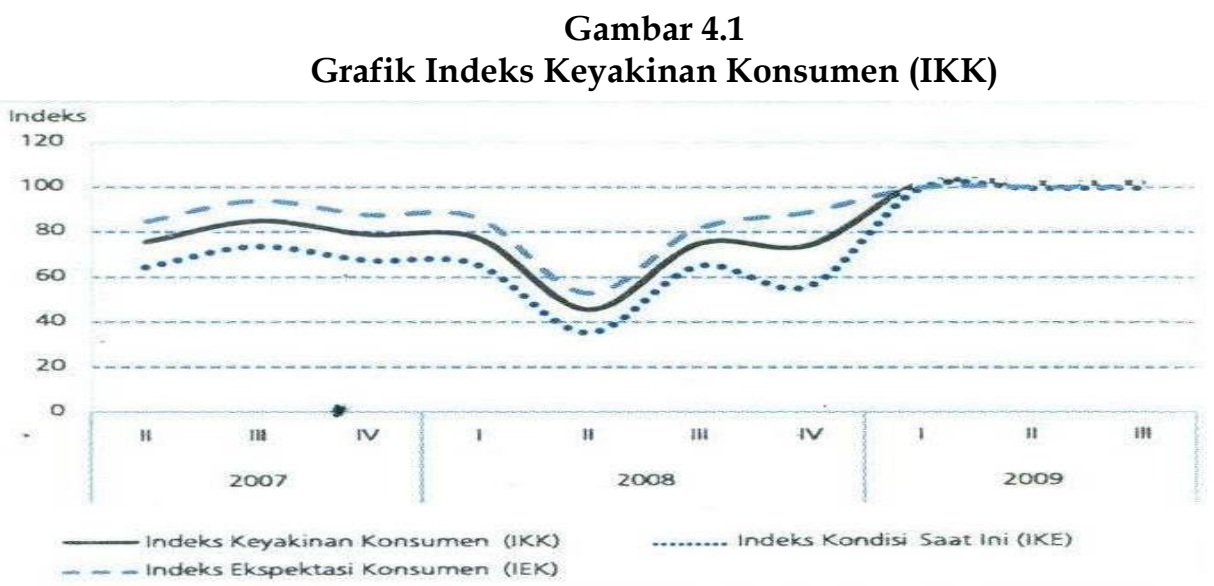

Sumber: Laporan IKK BI Yogyakarta 2009.

Bila dibandingkan dengan indeks tahun sebelumnya, IKK meningkat signifikan yaitu sebesar 26,82 poin hal ini mengindikasikan persepsi responden yang semakin optimis terhadap kondisi perekonomian ke depan yang tercermin dari meningkatnya nilai IEK sebesr 18,62 poin. Selain itu, kenaikan tersebut juga juga diikuti oleh optimisme responden kondisi ekonomi saat ini dengan peningkatan nilai IKE sebesr 35,02 poin.

Indeks kondisi ekonomi saat ini (IKE) pada triwulan III-2009 masih menunjukkan optimisme responden dengan peningkatan sebesar 0,07 poin dibandingkan dengan triwulan sebelumnya yaitu berada pada level 100,02. Meningkatnya IKE tersebut dipicu oleh meningkatnya tingkat optimisme responden terhadap indeks ketetapan waktu belanja dan indeks ketersediaan

Strategi lahan pekerjaan saat ini masing-masing sebesar 0,11 poin dan 0,18 poin, sedangkan

Pemasaran 
untuk kondisi penghasilan konsumen saat ini cenderung menurun tercermin dari penurunan indeks sebesar $-0,08$ poin.

Secara tahunan, IKE pada triwulan III-2009 mengalami kenaikan yang signifikan yaitu sebesar 35,02 poin yang dipicu oleh optimisme responden terhadap indeks ketetapan waktu belanja dan indeks ketersediaan lahan pekerjaan saat ini dibandingkan tahun lalu dengan kenaikan masin-masing sebesar 48,26 poin dan 70,48 poin. Meskipun konsumen merasakan kondisi penghasilan saat ini cenderung menurun yang tercermin dari penurunan indeks sebesar $-13,68$ poin dibandingkan periode yang sama tahun sebelumnya, namun konsumen tetap merasa optimis terhadap kondisi ekonomi saat ini.

Indeks ekspektasi konsumen (IEK) pada triwulan III 2009 masih menunjukkan kenaikan relatif tipis sebesar 0,02 poin yaitu pada level 100,30 yang didorong oleh membaiknya ekspektasi konsumen terhadap kondisi ekonomi dan ketersediaan lahan pekerjaan satu tahun ke depan dengan kenaikan masingmasing sebesar 0,04 poin dan 0,12 poin.

Perkiraan responden terhadap kondisi perekonomian 1 tahun ke depan akan semakin baik dibandingkan periode yang sama tahun sebelumnya yang tercermin pada kenaikan indeks kondisi ekonomi sebesar 18,47 poin. Kenaikan indeks tercatat cukup signifikan sehingga dapat menjadi faktor pendorong kenaikan indeks ekspekstasi ketersediaan lahan pekerjaan satu tahun mendatang yang tercatat sangat signifikan yaitu sebesar 73,56 poin. Sedangkan penghasilan satu tahun kedepan konsumen cenderung merasa pesimistis dengan penurunan indeks sebesar $-35,65$ poin walaupun masih berada pada level optimis. Hal ini menyimpulkan akan berkurangnya pengangguran dan jumlah penjualan barang meningkat seiring dengan meningkatnya indeks ekspektasi konsumen.

\section{Survei Penjualan Eceran Bank Indonesia Yogyakarta 2009}

Indeks penjualan riil tercatat sebesar 158,38 atau tumbuh sebesar 11,64\% sementara itu, secara tahunan indeks mengalami kenaikan sebesar 23,39\%. Kenaikan tersebut terutama berasal dari kenaikan penjualan pada kelompok suku cadang kendaraan.

Sebagian besar responden memperkirakan akan terjadi kenaikan harga umum baik 3 bulan maupun 6 bulan ke depan yang disebabkan kenaikan biaya produksi yang berasal dari kenaikan biaya bahan baku dan biaya distribusi khususnya berkaitan dengan suasana hari raya Idul Fitri, Natal dan Tahun Baru.

Secara umum, hampir semua indeks penjualan di setiap kelompok barang mengalami pertumbuhan positif. Secara tahunan (yoy) hasil survey mencatat hanya terdapat 2 kelompok komoditi yang mengalami penurunan terbesar yaitu $50,84 \%$ diikuti kelompok makanan dan tembakau yang mengalami penurunan sebesar $42,00 \%$. Adapun peningkatan indeks penjualan yang mengalami penurunan sebesar $42,00 \%$. Dan peningkatan indeks penjualan riil sebesar 108,60\% diikuti oleh kelompok pakaian dan perlengkapannya (104,01\%) kelompok perlengkapan rumah tangga $(83,76 \%)$ kelompok konstruksi $(61,07 \%)$ kelompok bahan bakar minyak $(42,68 \%)$ kelompok perlengkapan tulis $(21,46 \%)$ kelompok farmasi dan kosmetik (10,64\%).

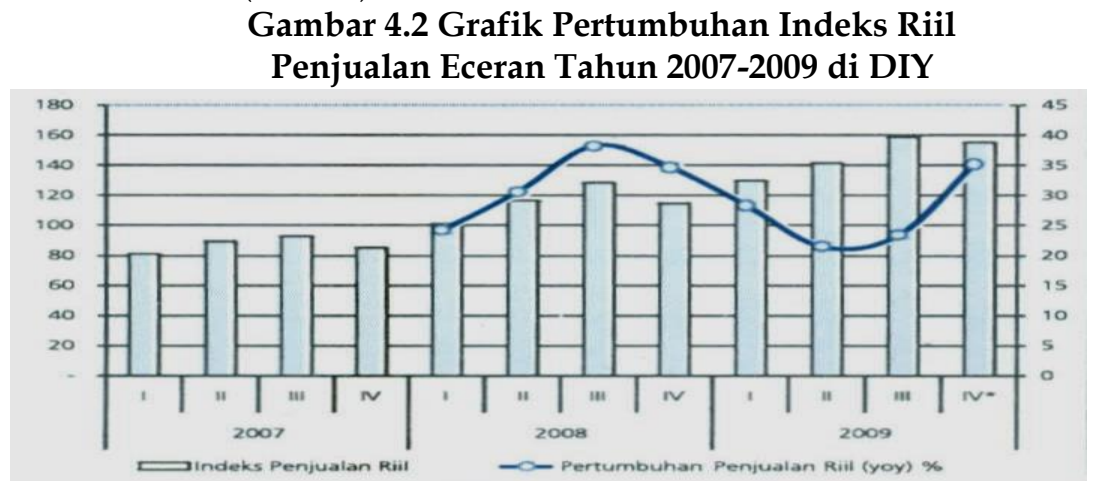

Arie
Rachmat 
Sumber: Bank Indonesia Yogyakarta (2009).

Sebagian besar responden menyatakan bahwa terdapat kecenderungan masyarakat umum mulai menaikkan kosumsi terhadap semua kelompok komoditi seiring dengan meningkatnya permintaan untuk menyambut bulan Ramadhan dan hari raya Idul Fitri. Hal ini tercermin dari naiknya indeks penjualan eceran pada 6 kelompok komoditi tersebut di atas.

\section{D.2. Indeks Penjualan Eceran}

Tabel 4.1

Indeks Penjualan Eceran

\begin{tabular}{|r|l|r|r|r|}
\hline \multirow{2}{*}{ No } & \multicolumn{2}{|c|}{ Kelompok Barang } & \multicolumn{3}{c|}{ yoy } \\
\cline { 3 - 5 } & & III-2007 & \multicolumn{1}{c|}{ III-2008 } & \multicolumn{1}{c|}{ III-2009 } \\
\hline $\mathbf{1}$ & Bahan Konstruksi & 71.98 & 101.74 & 163.88 \\
\hline $\mathbf{2}$ & Suku Cadang Kendaraan & 114.85 & 147.53 & 307.75 \\
\hline $\mathbf{3}$ & Perlengkapan Rumahtangga & 77.11 & 105.60 & 194.05 \\
\hline $\mathbf{4}$ & Barang Kerajinan dan Mainan & 84.46 & 294.73 & 144.89 \\
\hline $\mathbf{5}$ & Makanan \& Tembakau & 161.02 & 133.23 & 77.27 \\
\hline $\mathbf{6}$ & Pakaian \& Perlengkapannya & 59.38 & 82.40 & 168.11 \\
\hline $\mathbf{7}$ & Farmasi \& Kosmetik & 102.85 & 40.87 & 45.22 \\
\hline $\mathbf{8}$ & Bahan Bakar Minyak & 76.08 & 102.07 & 145.64 \\
\hline $\mathbf{9}$ & Perlengkapan Tulis & 88.12 & 147.03 & 178.59 \\
\hline & Rata-rata & $\mathbf{9 2 . 8 7}$ & $\mathbf{1 2 8 . 3 6}$ & $\mathbf{1 5 8 . 3 8}$ \\
\hline
\end{tabular}

Sumber: Bank Indonesia Yogyakarta (2009)

Analisis faktor internal kekuatan dan kelemahan dalam pengembangan strategi pemasaran di propinsi Daerah Istimewa Yogyakarta yang disajikan dalam Matrik evaluasi Faktor Internal seperti ditunjukkan pada tabel 4.2.

Tabel 4.4

Matrik Evaluasi Faktor Internal (EFI) Swalayan Pamella Dalam Pengembangan Strategi Pemasaran di DIY

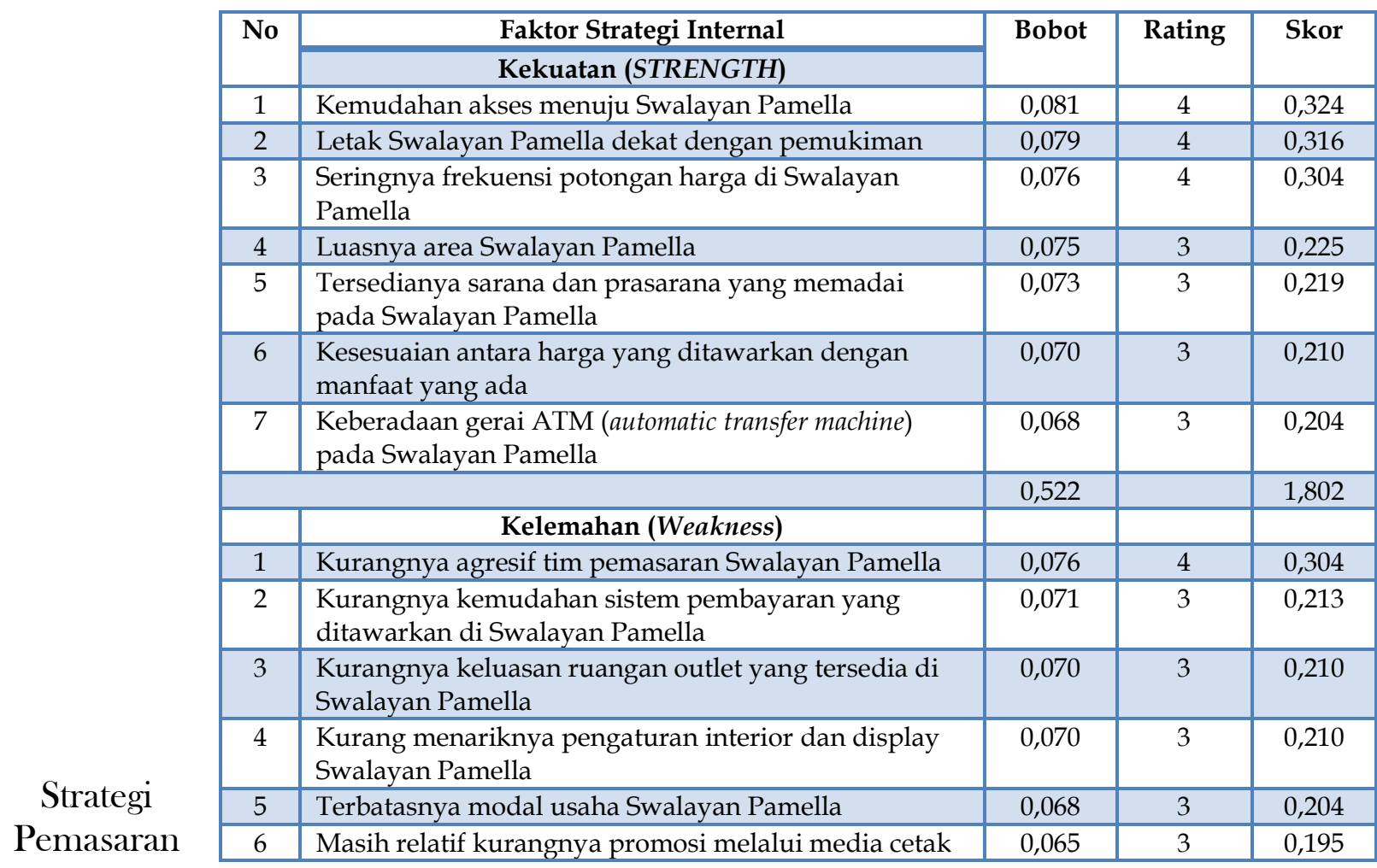




\begin{tabular}{|c|l|c|c|c|}
\hline \multirow{2}{*}{ No } & Faktor Strategi Internal & \multirow{2}{*}{ Bobot } & Rating & Skor \\
\cline { 2 - 5 } & \multicolumn{1}{|c|}{ Kekuatan (STRENGTH) } & & \\
\hline & dan elektronik yang dilakukan Swalayan Pamella & & \\
\hline 7 & Sedikitnya barang yang berlabel halal & 0,057 & 3 & 0,171 \\
\hline \multicolumn{2}{|c|}{ TOTAL } & 0,478 & & 1,507 \\
\hline \multicolumn{2}{|c|}{} & $\mathbf{1 , 0 0 0}$ & & $\mathbf{3 , 3 0 9}$ \\
\hline
\end{tabular}

Sumber : Hasil analisis data primer.

Analisis faktor eksternal peluang dan tantangan dalam pengembangan strategi pemasaran di propinsi DIY disajikan dalam Matrik evaluasi Faktor Eksternal seperti ditunjukan pada tabel 4.3

Tabel 4.5

Matrik Evaluasi Faktor Eksternal (EFE) Swalayan Pamella dalam Pengembangan Strategi Pemasaran di DIY

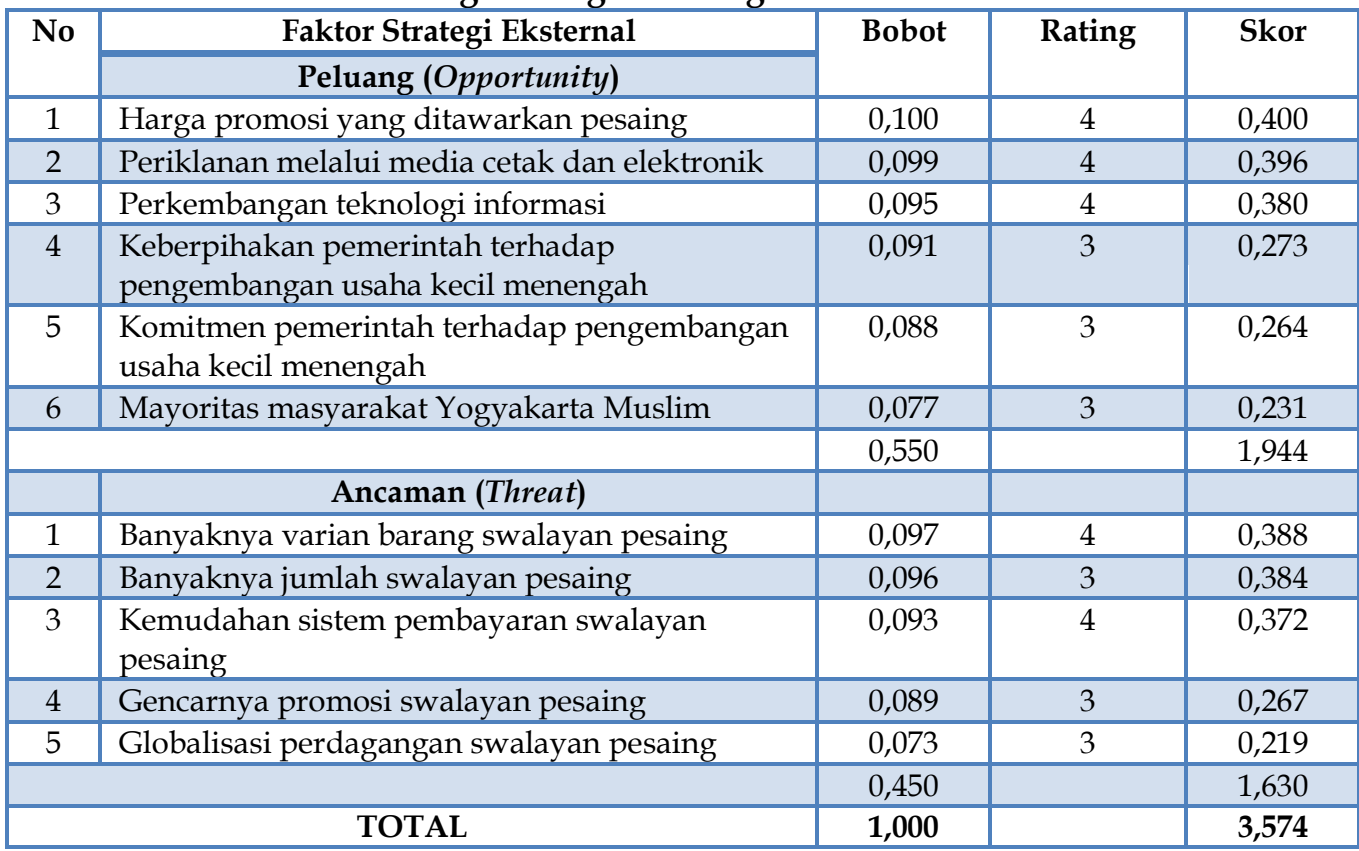

Sumber: Hasil analisis data primer .

\section{D.3. Analisis Matrik Internal-Eksternal}

Hasil evaluasi faktor internal dan eksternal tersebut menunjukkan nilai eksternal sebesar 3,309 dan internal sebesar 3,574. Artinya posisi pengembangan pemasaran Swalayan Pamella di DIY berada di kuadran kesatu pada matrik internal-eksternal pada Gambar 4. 3. Pada Posisi ini strategi yang terbaik dilakukan oleh Swalayan Pamella adalah strategi Growth. Penerapan strategi Growth berarti bahwa Swalayan Pamella di DIY dalam mengembangkan strategi pemasaran melaksanakan strategi penetrasi pasar dengan meningkatkan program yang telah ada dan melakukan pengembangan program. Analisis matrik internaleksternal faktor pengembangan strategi pemasaran swalayan pamella disajikan pada gambar 4.3: 
Gambar 4.3

Posisi Pengembangan Strategi Pemasaran Swalayan Pamella di DIY pada Matrik Internal-Eksternal

\begin{tabular}{|c|c|c|}
\hline Kuat & Sedang & Lema \\
\hline 4.0 & 3,0 & 1,0 \\
\hline $\begin{array}{c}\text { I } \\
\text { Growth }\end{array}$ & $\begin{array}{c}\text { II } \\
\text { Growth }\end{array}$ & $\begin{array}{c}\text { III } \\
\text { Retrenchment }\end{array}$ \\
\hline $\begin{array}{c}\text { IV } \\
\text { Stability }\end{array}$ & $\begin{array}{c}\mathrm{V} \\
\text { Growth/Stability }\end{array}$ & $\begin{array}{c}\text { VI } \\
\text { Retrenchment }\end{array}$ \\
\hline $\begin{array}{c}\text { VII } \\
\text { Growth }\end{array}$ & $\begin{array}{c}\text { VIII } \\
\text { Growth }\end{array}$ & $\begin{array}{c}\text { IX } \\
\text { Retrenhment }\end{array}$ \\
\hline
\end{tabular}

Sumber: Data Primer (diolah)

\section{D.4. Sintesis Penilaian}

Sintesis hasil penilaian merupakan tahap akhir dari AHP. Pada dasarnya, sintesis ini merupakan penjumlahan dari bobot yang diperoleh setiap pilihan pada masing-masing kriteria setelah diberi bobot kriteria tersebut. Hal yang identik dilakukan untuk pilihan 1, 2, 3 dan 4. Dengan membandingkan nilai yang peroleh masing-masing pilihan, prioritas dapat disusun berdasarkan besarnya nilai tersebut. Semakin tinggi nilai suatu pilihan, semakin tinggi prioritasnya, dan sebaliknya.

\section{D.5. Hasil Analasis Penilaian/Pembandingan Elemen}

Tabel 4.6

Penilaian Kriteria pada Pemasaran Swalayan Pamella di DIY

\begin{tabular}{|l|l|}
\hline \multicolumn{1}{|c|}{ Kriteria } & Bobot \\
\hline Diversifikasi Barang & 0,3184 \\
\hline Sistem Distribusi Barang & 0,2990 \\
\hline Daya Beli Masyarakat & 0,2107 \\
\hline Ketersediaan Barang & 0,1719 \\
\hline
\end{tabular}

Sumber: Data Primer (diolah)

\section{D.6. Sintesis Penilaian}

Tahap akhir yang harus dilakukan dalam penggunaan AHP sebagai model pembuatan keputusan adalah sintesis penilaian yang merupakan penjumlahan dari bobot yang diperoleh di setiap pilihan pada masingmasing kriteria setelah diberi bobot dari kriteria tersebut. Secara sederhana, hasil dari sintesis penilaian yang telah dilakukan pada studi kasus tentang pemasaran di Swalayan Pamella Yogyakarta dengan menggunakan AHP sebagai model pembuatan keputusan disajikan pada tabel 4.11.

\section{Tabel 4.11}

\section{Sintesis Hasil Penilaian Global Strategi Pemasaran Swalayan Pamella di DIY} Berdasarkan Empat Kriteria

\begin{tabular}{c|l|c|}
\cline { 2 - 3 } & \multicolumn{1}{c|}{ Aternatif Strategi } & Bobot \\
\cline { 2 - 3 } Strategi & $\begin{array}{l}\text { Pengembangan diversifikasi barang, sistem distribusi barang, } \\
\text { bekerja sama dengan pengusaha kecil dan koperasi pedesaan }\end{array}$ & 0,2679 \\
\cline { 2 - 3 } Pemasaran & $\begin{array}{l}\text { Merubah posisi tata letak barang dan menambah jumlah } \\
\text { persediaan untuk meningkatkan pelayanan }\end{array}$ & 0,2611 \\
\cline { 2 - 3 }
\end{tabular}




\begin{tabular}{|l|c|}
\hline $\begin{array}{l}\text { Mendesain ruangan dengan konsep yang menarik konsumen, } \\
\text { menambah varian barang dan membuat promosi yang lebih baik }\end{array}$ & 0,2505 \\
\hline $\begin{array}{l}\text { Bersinergi dengan pemerintah dalam mengembangkan usaha } \\
\text { dengan cara mengakses bantuan dan mengikuti } \\
\text { pelatihan/workshop Disperindagkop }\end{array}$ & 0,2205 \\
\hline
\end{tabular}

Sumber: Data Primer (diolah)

Secara lebih jelas hasil penilaian alternatif strategi berdasarkan kriteria disajikan pada gambar 4.6 dibawah ini.

\section{Gambar 4.6 \\ Hasil Penilaian Alternatif Strategi Berdasarkan Kriteria}

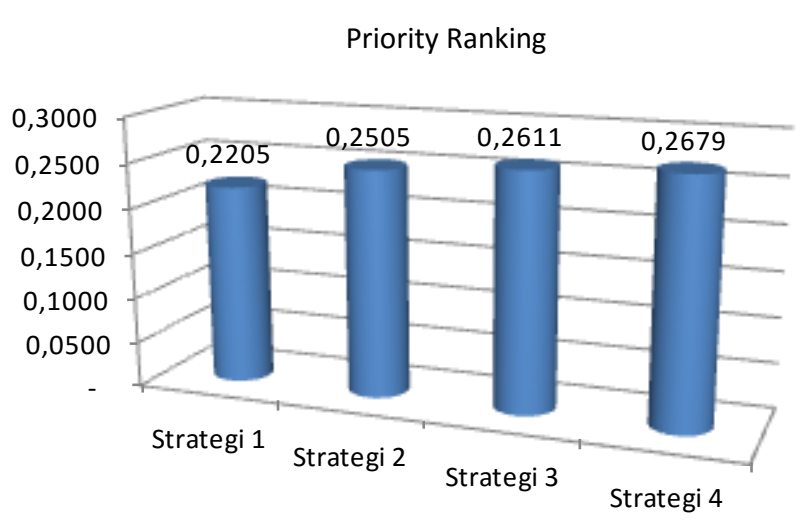

Sumber: Data Primer (diolah)

\section{D.7. Hirarki Strategi Pemasaran Swalayan Pamella \\ Gambar 4.7}

Hirarki Pengembangan Strategi Pemasaran Swalayan Pamella

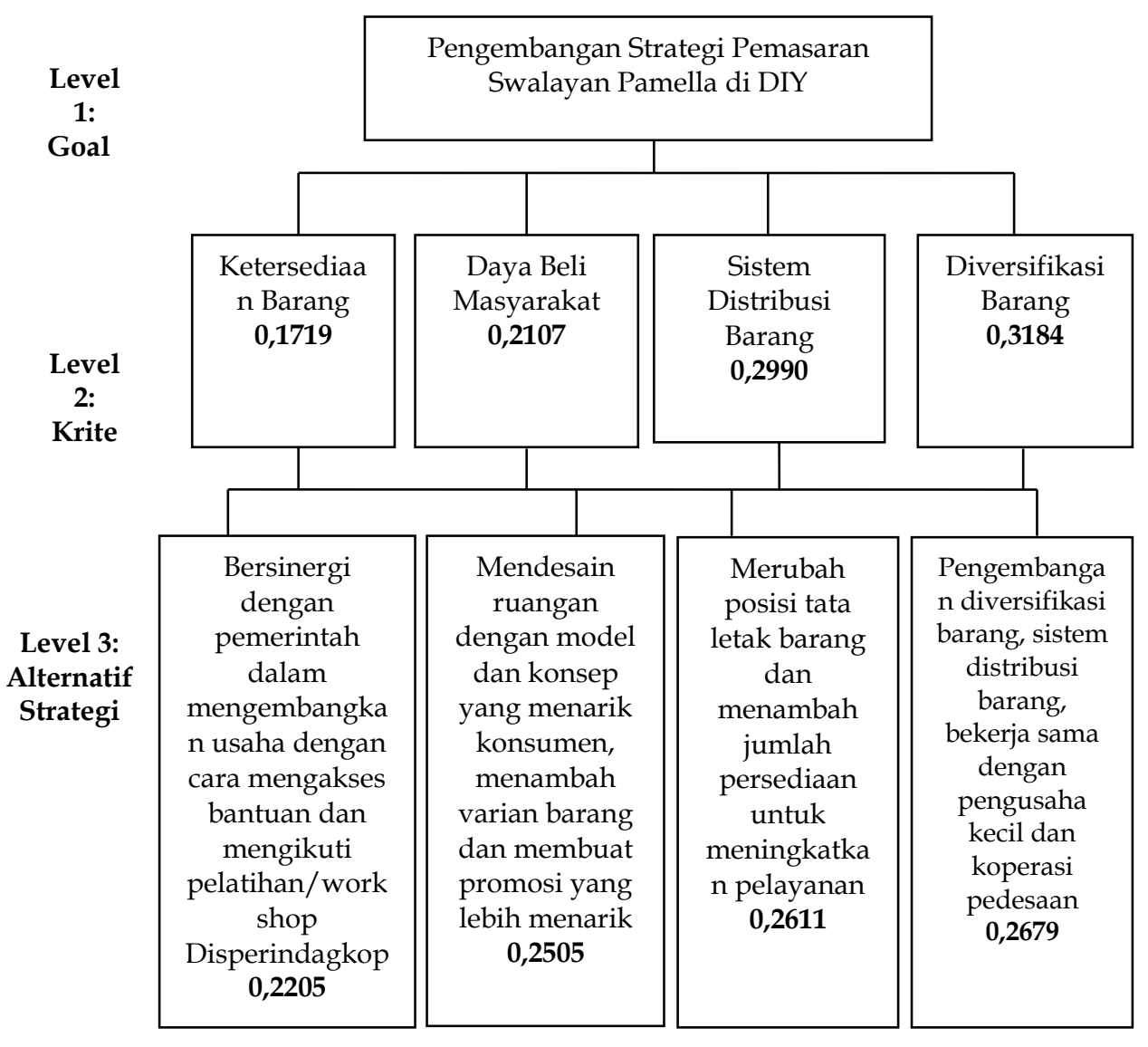

Arie

Rachmat 
Sumber: Data Primer (diolah)

\section{E.1. Kesimpulan}

Berdasarkan tujuan penelitian dan hasil analisis data, dapat dirumuskan beberapa kesimpulan sebagai berikut:

1. Strategi alternatif yang dirumuskan dari diagram matrik SWOT yang memadukan antara IFAS (Strength, Weakness) dan EFAS (Opportunity, Threat) di hasilkan 4 alternatif strategi: Strategi Strength dan Opportunity (SO) bersinergi dengan pemerintah dalam mengembangkan usaha dengan cara mengakses bantuan dan mengikuti pelatihan/workshop Disperindagkop. Strategi Weakness dan Opportunity (WO) adalah mendesain ruangan dengan model dan konsep yang menarik konsumen, menambah varian barang dan membuat promosi yang lebih menarik. Strategi Strength dan Threat (ST) yaitu merubah posisi tata letak barang dan menambah jumlah persediaan untuk meningkatkan pelayanan. Strategi Weakness dan Threat (WT) adalah pengembangan diversifikasi barang, sistem distribusi barang, bekerjasama dengan pengusaha kecil dan koperasi pedesaan.

2. Melalui Analitical Hierarchy Process (AHP) dihasilkan urutan skala prioritas alternatif strategi yang dihasilkan dari analisis SWOT. Alternatif strategi skala prioritas pertama adalah pengembangan diversifikasi barang, sistem distribusi barang dan bekerjasama dengan pengusaha kecil dan koperasi pedesaan. Alternatif strategi prioritas kedua yaitu merubah posisi tata letak barang dan menambah jumlah persediaan barang untuk meningkatkan pelayanan. Alternatif strategi ketiga adalah mendesain ruangan dengan model dan konsep yang lebih menarik konsumen, menambah varian barang dan membuat promosi yang lebih menarik. Alternatif strategi prioritas keempat yaitu bersinergi dengan pemerintah dalam mengembangkan usaha dengan cara mengakses bantuan dan mengikuti pelatihan/workshop Disperindagkop.

\subsection{Saran}

Berdasarkan kesimpulan dari penelitian ini, dapat dikemukakan beberapa saran sebagai berikut:

1. Untuk mengembangkan strategi pemasaran Swalayan Pamella di DIY, tim pemasaran hendaknya perlu mengikuti pelatihan tentang pemasaran, menambah varian barang berlabel halal, membuat slogan tulisan yang mengajarkan nilai-nilai Islam dan menerapkannya dalam perniagaan. Memberikan motivasi kepada tim pemasaran dalam etika perdagangan yang berlaku dalam Islam. Mengangkat Konsultan dalam memutuskan strategi pemasaran. Mengadakan penelitian tentang tingkat kepuasan konsumen Swalayan Pamella.

2. Untuk strategi pemasaran Swalayan Pamella di DIY agar memprioritaskan strategi pengembangan diversifikasi barang, sistem distribusi barang, bekerja sama dengan perbankan Islam dan koperasi pedesaaan.

\section{DAFTAR PUSTAKA}

Afzalurrahman. 2000. Muhammad sebagai Seorang Pedagang. Jakarta: Yayasan Swarna Bhumy.

Al-Quran dan Tarjamah Departemen Agama Republik Indonesia. Bandung: Syaamil.

Antonio, M. S. 2004. Bisnis Cara Rasullulah. Jakarta: Republika.

Strategi Arikunto, Suharsimi. 2006. Prosedur Penelitian Suatu Pendekatan Praktek. Jakarta: Rineka Cipta. 
Assauri, Sofyan. 2002. Manajemen Pemasaran Dasar Konsep dan Strategi. Jakarta: Raja Grafindo Persada.

Badawi, zaki, ahmad. 1984. A Dictionary Of Economic, English - French - Arabic, Kohiro.

Bank Indonesia, 2009. Laporan Perkembangan Perekonomian Daerah Istimewa Yogyakarta. Triwulan III.

Craven, David W. 1996. Pemasaran Strategis. Jakarta: Glora Aksara Pratama.

David, Fred. R. 2002. Manajemen Strategis Konsep. Jakarta: Edisi 7, PT. Prenhalindo.

http/www.BI.go.id

http/www.BPS DIY.go.id

Kartajaya, H. 2005. Aa Gym A Spiritual Marketer. Jakarta: Ikrar Mandiri Abadi.

Kartajaya, H. dan Sula, S.M. 2006. Syari'ah Marketing. Bandung: Mizan Pustaka.

Keith, J.R. 1960. The Marketing Revolution. Journal of Marketing.

Khan, U. and Dhar, R. 2006. Lincensing Effect in Consumer Choise. Journal of Marketing Research. May. 259-266.

Kotler, P. 1997. Marketing Management: Analysis, Planing, Implementation, and Control, $9^{\text {th }}$ ed. Englewood Cliffs, NJ: Prentice-Hall Inc.

Kotler, P. 2009. Manajemen Pemasaran. Jakarta: Indeks.

Krishnamurthi, and Papatla, P. 1996. Measuring the Dynamic Effect of Promotions on Brand Choice. Journal of Marketing Research. February. 20-35.

Ma'arif, M dan Hendri Tanjung, 2003. Teknik-Teknik Kuantitatif Untuk Manajemen, Jakarta: Grasindo.

Mintzberg, H. And Quinn J, 1992. The Strategy Proces Concept and Contexts. Prentice Hall International Inc.

Moleong, L.J. 1997. Metodologi Penelitian Kualitatif. Bandung: P.T. Remaja Rosda Karya.

Plastrik, and Osborne, D. 1997. Bunishing Bereaucracy: The Five Strategis For Reinventing Government. New York, Usa: Penguin Group.

Purwanto, I. 2007. Manajemen Strategi. Bandung: Yrama Widya.

Rangkuti, Freddy. 2004. Analisis SWOT Teknik Membedah Kasus Bisnis. Jakarta: Gramedia Pustaka Utama.

Saaty, T.L. 1980. The Analitic Hierarchy Process. McGraw-Hill.Inc,. USA.

Saaty, T.L. 1983. The Analitic Hierarchy Process: Planning, Priority Setting, Resources Allocation. McGraw Hill, New York.

Saaty, T.L. 1990. Analytical Hierarchy Process. University of Pittsburgh. Pennsylvania.19-28.

Salim, A. 2001. Syarah Bulughul Maram. Surabaya: Halim Jaya Surabaya.

Stanton, W.J. 2001. Fundamentals of Marketing. Mc Grow-Hill Book Company.

Sugiyono. 2009. Metode Penelitian Kuantitatif Kualitatif Dan R\&D, Cetakan ke 8. Bandung: CV Alfabeta.

Swastha, B.DH. 2000. Azas-azas Marketing. Yogyakarta: Liberty.

Tjiptono, Fandy. 2008. Strategi Pemasaran, Yogyakarta: Andi.

Usman, W. 2004. Metode Kuantitatif. Jakarta: Universitas Terbuka.

Wheelen, TL and J.D. Hunger, 2002. Strategic Management Formulation and Implementation. IRWIN.

Arie

Rachmat 